\title{
Closed reduction percutaneous pinning versus open reduction internal fixation in the treatment of intraarticular distal radius fractures: Mean four-year results
}

\author{
Sertac Saruhan, M.D., ${ }^{1}$ (i) Cumhur Deniz Davulcu, M.D. ${ }^{2}$
}

\author{
1'Department of Orthopaedics and Traumatology, Bozyaka Training and Research Hospital, İzmir-Turkey \\ ${ }^{2}$ Department of Orthopaedics and Traumatology, Katip Çelebi University, Atatürk Training and Research Hospital, İzmir-Turkey
}

\begin{abstract}
BACKGROUND: This study was performed to compare the results of closed reduction percutaneous pinning (CRPP) versus open reduction internal fixation with a volar locking plate (ORIF) in the treatment of intraarticular distal radius fractures (IDRF) average four-year follow-up.

METHODS: In this study, 43 patients had unilateral intraarticular distal radius fractures (type $B$ and C) treated with CRPP ( $=19$; II males and eight females) and ORIF ( $n=24$; I 4 males and 10 females) were retrospectively evaluated. The mean follow-up was 50.3 months (12-74) at the CRPP group and 45.2 months (40-65) at the ORIF group. The mean age was 50.8 years (29-73) in the CRPP group and 5 I.5 (19-75) in the ORIF group. The patients were evaluated functionally and radiologically at the last follow-up.

RESULTS: There was no statistically significant difference between the groups concerning follow-up, age, and gender. However, there was no statistical difference concerning grip power and the range of motion. The Disabilities of the Arm, Shoulder and Hand Score (Q-DASH) was better in the ORIF group. Voler tilt and radial height measurements were statistically significantly better in the ORIF group. Degenerative arthritis was $63 \%$ in the CRPP group and $41 \%$ in the ORIF group, and there was no statistically significant difference.
\end{abstract}

CONCLUSION: ORIF with a volar locking plate has better functional and radiological results than CRPP in IDRF patients' average four-year follow-up.

Keywords: Distal radius fractures; intraarticular distal radius fractures open reduction internal fixation; percutaneous pinning; volar locking plate.

\section{INTRODUCTION}

Distal radial fractures are the most common fracture of the upper extremities. ${ }^{[1]}$ Fractures of the distal part of the radius in younger adults are usually the result of high-energy trauma and have intra-articular involvement; in elderly patients, low energy trauma and osteoporosis may cause an intraarticular fracture. In the treatment of IDRF, percutaneous pinning, external fixator (EF), plates and their combinations could be used after closed or open reduction. ${ }^{[2-6]}$ Generally, CRPP with EF and open reduction internal fixation with vo- lar locking plates are accepted methods to treat IDRF. The treatment aim is to obtain better functional results by anatomically restoring the joint. ${ }^{[7]}$ CRPP with or without EF is a minimally invasive and cost-effective method, but complications include reduction lost, pin tract infection, stiffness, and complex regional pain syndrome are their own disadvantages. Recently, open reduction internal fixation (ORIF) with a volar locking plate is the preferred and more popular method. ${ }^{[2-8]}$ It allows an immediate range of motion of the wrist while maintaining alignment, resulting in a rapid functional recovery, but this method is more expensive and surgically

Cite this article as: Saruhan S, Davulcu CD. Closed reduction percutaneous pinning versus open reduction internal fixation in the treatment of intraarticular distal radius fractures: mean four-year results. Ulus Travma Acil Cerrahi Derg 2021;27:238-242.

Address for correspondence: Cumhur Deniz Davulcu, M.D.

İzmir Bozyaka Eğitim ve Araştırma Hastanesi, Ortopedi ve Travmatoloji Kliniği, İzmir, Turkey

Tel: +90 232 - 2434343 E-mail: cumhurdd@yahoo.com

Ulus Travma Acil Cerrahi Derg 2021;27(2):238-242 DOI: 10.14744/tjtes.2020.28934 Submitted: 03.02.2020 Accepted: 10.04.2020

Copyright 2021 Turkish Association of Trauma and Emergency Surgery 
more demanding, especially in intraarticular fractures. Studies comparing CRPP without using EF and ORIF with locking volar plates are very rare in the literature. The follow-up period of these studies is usually less than one year, and the types of fractures compared are not homogeneous. ${ }^{[4,6,8-10]}$ In this study, we aimed to compare CRPP without using EF to ORIF with a volar locking plate functionally and radiologically in intraarticular distal radius fractures (IDRF) patients' average four-year follow-up.

\section{MATERIALS AND METHODS}

Between 2012 and 2018, 43 patients with unilateral IDRF were studied retrospectively. Initially, only AO type B and C fractures were included in this study for a consistent comparison between groups. Of these 43 patients, 19 patients had CRPP without EF, and 24 patients had ORIF with a volar locking plate. Cases with pathologic fractures, patients under 18 years of age, bilateral cases, and ipsilateral upper limb injuries were excluded from this study. The research protocol was approved by the local ethics committee.

The fractures were assessed by wrist radiograph and computerized tomography before surgery. The AO classification system was used for typing the fractures. Demographics of cases and distribution of fracture types are given in Table I. The method of fixation was based on randomization because of problems, such as the medical condition of the patient, operation in emergency conditions and material supply.

CRPP was performed with two to five k-wires without using $E F$, according to the stabilization requirement, after closed reduction under the scope. ORIF was performed with the palmar Henry approach under a tourniquet, using a 2.4-mm anatomic locking plate.

In the CRPP group, the union was checked with radiographs six weeks later, then, the plaster and $k$-wires were removed, the rehabilitation program was started. In the ORIF group, each patient was placed in a forearm brace until the sutures were removed. After suture removal, the brace was removed wrist and finger exercises were started. At last control, functional and radiologic evaluation of the patients was performed. Flexion-extension, ulnar-radial deviation, and pronation-supination were measured in both wrists with a goniometer. The functional results were evaluated using Q-DASH and MAYO scores in both groups. Grip strength was measured in both wrists with a Jamar dynamometer (model $\mathrm{SH}$ 500 I, Saehan Corporation Masan, South Korea).

Radial height, radial inclination, volar tilt, ulnar variance, degenerative arthritis, and articular step were evaluated radiologically in the anteroposterior and lateral wrist radiographs. All of the statistical analyses were performed using SPSS Statistics for Windows version 15.0 (IBM, Armonk, NY, USA). Differences between the two groups were analysed using the chi-square test, Fisher's exact test, Mann-Whitney U-test, and Student's t-test, where appropriate. The results were evaluated with a $95 \%$ confidence interval, and a $p$-value of less than 0.05 was considered significant.

\section{RESULTS}

No difference was found between the groups regarding age, gender, follow-up period and dominant side (Table I). Wrist flexion-extension, pronation-supination arch, radial-ulnar deviation, and grip strength were evaluated; no statistically significant differences were found between the groups. There was a difference regarding Q-DASH scores between the groups. ORIF was statistically better than CRPP (Table 2).

At last, follow-up, when the groups were compared radiologically, there was a difference regarding radial height and volar tilt between the groups. The ORIF group was better than CRPP regarding radial height and volar tilt. No difference was found regarding radial inclination and ulnar variance. Degenerative arthritis was seen in II patients (63\%) in the CRPP group and in 10 (4I\%) patients in the ORIF group; there was no difference between the groups (Table 3 ).

Table I. Demographics and types of fractures

\begin{tabular}{lccc}
\hline & CRPP & ORIF & P \\
\hline Mean age (years) & $50.8(29-73)$ & $51.5(19-75)$ & 0.59 \\
Gender (male/female) & $\mathrm{I} / \mathrm{8}$ & $14 / 10$ & 0.63 \\
Mean follow up (month) & $50.3(12-74)$ & $45.2(40-65)$ & 0.72 \\
Fracture types & & & \\
$\quad$ B & 6 & 4 & \\
C & 13 & 20 & \\
\hline
\end{tabular}

CRPP: Closed reduction percutaneous pinning; ORIF: Open reduction internal fixation.

Table 2. Clinical and functional evaluation

\begin{tabular}{lccc}
\hline & $\begin{array}{c}\text { CRPP } \\
(\mathbf{n}=19)\end{array}$ & $\begin{array}{c}\text { ORIF } \\
(\mathbf{n = 2 4 )}\end{array}$ & p \\
\hline Flexion-extension arch & 99.3 & 110.1 & 0.26 \\
Radial-Ulnar deviation arch & 36.2 & 54.14 & 0.57 \\
Pronation-supination arch & 149.3 & 167.4 & 0.54 \\
Grip power (\%) & 76.2 & 80.63 & 0.46 \\
Q-DASH & 25.45 & 11.74 & $0.04^{*}$ \\
MAYO SCORE, n (\%) & & & \\
$\quad$ Good-Excellent & $12(63 \%)$ & $20(83 \%)$ & \\
\multicolumn{1}{c}{ Mild-Worst } & $7(37 \%)$ & $4(17 \%)$ & \\
\hline
\end{tabular}

Bold numbers and the *mark significant difference. CRPP: Closed reduction percutaneous pinning; ORIF: Open reduction internal fixation. 
Table 3. Radiologic evaluation

\begin{tabular}{lccc}
\hline & $\begin{array}{c}\text { CRPP } \\
(\mathbf{n}=19)\end{array}$ & $\begin{array}{c}\text { ORIF } \\
(\mathbf{n}=\mathbf{2 4})\end{array}$ & p \\
\hline Radial height $(\mathrm{mm})$ & $9.1 \mathrm{I}$ & 13.39 & $0.02^{*}$ \\
Radial inclination $\left({ }^{\circ}\right)$ & 20.5 & 19.99 & 0.77 \\
Voler tilt $\left(^{\circ}\right)$ & -5.10 & 9.36 & $0.00^{*}$ \\
Ulnar variants $(\mathrm{mm})$ & $2,8 \mathrm{I}$ & -2.04 & 0.10 \\
Degenerative arthritis $(\mathrm{n})$ & $\mathrm{II}(\% 63)$ & $10(\% 4 \mathrm{I})$ & 0.16 \\
Articular step off $(\mathrm{mm})$ & 6 (mean: I.65) & 7 (mean: 0.7) & 0.90 \\
\hline
\end{tabular}

Bold numbers and the *mark significant differences. CRPP: Closed reduction percutaneous pinning; ORIF: Open reduction internal fixation.

Table 4. Complications

CRPP $(n=19)$

ORIF $(n=24)$

Minor

Superficialinfection

CRPS

CTS

Total

Major

$\begin{array}{lcc}\text { Reoperation } & 1^{*} & 2^{* *} \\ \text { Nonunion } & 1 & 0 \\ \text { Total } & 2(10 \%) & 2(8 \%)\end{array}$

*Open reduction and pin fixation with autografting due to loss of reduction. **Plate removal at first eight weeks due to severe pain and migration of screws. CRPP: Closed reduction percutaneous pinning; ORIF: Open reduction internal fixation; CRPS: complex regional pain syndrome; CTS: Carpal tunnel syndrome.

Reoperation and nonunion were defined as major complications; superficial infection, complex regional pain syndrome (CRPS) and carpal tunnel syndrome (CTS) were defined as minor complications. Complications are listed in Table 4.

\section{DISCUSSION}

The determination of the appropriate treatment method in IDRF can be achieved only by comparative studies. When the studies in the literature are examined, the groups are not homogenous regarding age distribution, fracture types and treatment methods applied. Therefore, the outcomes of these studies may not be reliable.

Rozental et al. ${ }^{[10]}$ reported that ORIF with a volar plate and CRPP in IDRF patients in their study, in which the groups included unstable extra-articular fractures and no $\mathrm{C} 3$ fractures. They stated that the ORIF group achieved better functional results in the early period (first nine weeks), but no difference was found at the end of the first year. Also stated in the same study that this was because the short plaster time and early range of motion started and ORIF was more advantageous in terms of returning to daily life earlier. Kreder ${ }^{[6]}$ found no difference in functional results from the sixth month in his study comparing CRPP with ORIF with a plate in patients with IDRF. In his study, some patients in the CRPP group applied external fixator. Additionally, the ORIF group included both volar and dorsal plates. At the two-year follow-up, Kreder indicated that indirect reduction and percutaneous pinning had better functional results when the intra-articular step and gap were minimized. Since our study does not have short-term data, we are not convinced about early functional results. In our study, Q-DASH scores statistically better in the ORIF group and although other functional parameters (range of motion and grip power) were not statistically better, it seems to be a better trend in the ORIF group at the end of the mean four years follow-up. Although KRPP is a minimally invasive method, it does not create devascularization in the fractured area. It is considered that it has a positive contribution to recovery; we believe that the positive effect of early movement on functional outcomes is more prominent in patients with ORIF with the volar plate.

In our study, volar tilt and radial length were statistically significantly better in the ORIF group. However, there were no significant differences between the groups concerning the other radiologic parameters. With these results, it can be said that the wires cause insufficient fixation and do not prevent collapse in the fracture's sides, especially in multi fragmented fractures. Thus, this leads to the deterioration of the radiological parameters. However, in some intraarticular fractures, fragments are very distally located; it is challenging to use a plate. ${ }^{[1]}$ The appropriate treatment for these fractures seems to be fixation by wires, with a closed or mini-open method. ${ }^{[4,12]}$ ORIF with volar plate has been shown to give better results radiologically in most studies. ${ }^{[2,4,8,13]}$ However, in Kreder's study, there was no significant difference6. Poor radiologic results with ORIF with a volar plate may be concerned with multi-fragmented and displaced intraarticular fracture type (C3) and osteoporosis. We think that ORIF with a volar plate is superior in correcting radiological parameters due to the anatomical features of the plate.

The amount of the articular step and gap is the determinant of future degenerative arthritis. It is shown in the literature that degenerative arthritis is limited in the well-restored joint surface. ${ }^{[7,14]}$ Lutz suggests that an increase in articular cavity depth and anteroposterior distance of the lunate fossa should be avoided to improve results following IDRF. $^{[15]}$ It has been observed in some studies that degenerative arthritis in the upper extremities progresses slowly and arthritis is not correlated with clinical symptoms and radiology. ${ }^{[7,15]}$ Concerning CRPP, long-term and comparative studies on degenerative arthritis are inadequate. ${ }^{[4,8]}$ Leung et al. ${ }^{[8]}$ demonstrated that the plate fixation group was significantly better than those for the external fixation combined with the pin group regarding degenerative arthritis at twenty-four months of follow-up in 
his study. In our study, the incidence of degenerative arthritis was $63 \%$ in the CRPP group and $41 \%$ in the ORIF group. No statistically significant difference was observed between the results, but in the ORIF group, the rate of comminuted fracture types (C2 and C3) was higher than CRPP (66\% versus $23 \%$ ), and the degenerative arthritis rate was lower. These results suggest that ORIF with a volar palmar plate reduces the rate of development degenerative arthritis by providing better restoration of the joint and preservation of reduction in patients with IDRF.

IDRF is open to various complications depending on the surgical method applied. In the meta-analysis study of Chaudhry et al., ${ }^{[6]}$ comparing ORIF with plate and CRPP, they stated that there was no significant difference in the complication rates, including deep infection neurological (including CTS), tendon rupture and reoperation. Kreder found a lower complication rate in the CRPP group in his study, but Rosenthal ${ }^{[10]}$ and Gereli ${ }^{[4]}$ reported that ORIF with a volar plate was superior to the CRPP concerning complication rates. It is not possible to reach a definitive conclusion about which method is superior in terms of complications from these studies. The use of EF could be considered an important factor in the CRRP group. In our study, the complication rate was found in $57 \%$ of the KRPP group, and 10\% of them were major complications (Table 4). Although EF was not used in the CRPP group, we believe that this complication rate is high.

Limitations of this study are a relatively low number of patients, retrospectively and low homogeneity concerning fracture types and ages. Treatment optimization was not fully achieved due to patient selection and treatment method decisions made by different surgeons. However, due to the lack of a comparative study with an average of four years of follow-up in the literature, we think it makes our study valuable.

\section{Conclusion}

As a result of an average of four years of follow-up, we concluded that ORIF with a volar locked plate is a superior treatment method than CRPP concerning complication rate, degenerative osteoarthritis development and functional results in patients with IDRF.

Ethics Committee Approval: Ethics committee approval was received for this study from the İzmir Katip Çelebi University Medical Faculty Ethics Committee (Date: 20.02.2019, No: 98).

Peer-review: Internally peer-reviewed.

Authorship Contributions: Concept: S.S., C.D.D.; Design: S.S.; Supervision: C.D.D.; Resource: S.S.; Materials: S.S.; Data: S.S.; Analysis: C.D.D.; Literature search: S.S., C.D.D.; Writing: S.S., C.D.D.; Critical revision: C.D.D.

Conflict of Interest: None declared.
Financial Disclosure: The authors declared that this study has received no financial support.

\section{REFERENCES}

1. Garcia-Elias M, Folgar MA. The management of wrist injuries: an international perspective. Injury 2006;37:1049-56. [CrossRef]

2. Zengin EC, Ozcan C, Aslan C, Bulut T, Sener M. Cast immobilization versus volar locking plate fixation of $\mathrm{AO}$ type $\mathrm{C}$ distal radial fractures in patients aged 60 years and older. Acta Orthop Traumatol Turc 2019;53:15-8. [CrossRef]

3. Chen CE, Juhn RJ, Ko JY. Treatment of distal radius fractures with percutaneous pinning and pin-in-plaster. Hand (N Y) 2008;3:245-50.

4. Gereli A, Nalbantoğlu U, Kocaoğlu B, Türkmen M. Comparison of palmar locking plate and $\mathrm{K}$-wire augmented external fixation for intra-articular and comminuted distal radius fractures. Acta Orthop Traumatol Turc 2010;44:212-9. [CrossRef]

5. Jakubietz MG, Gruenert JG, Jakubietz RG. Palmar and dorsal fixed-angle plates in AO C-type fractures of the distal radius: is there an advantage of palmar plates in the long term?. J Orthop Surg Res 2012;7:8. [CrossRef]

6. Kreder HJ, Hanel DP, Agel J, McKee M, Schemitsch EH, Trumble TE, et al. Indirect reduction and percutaneous fixation versus open reduction and internal fixation for displaced intra-articular fractures of the distal radius: a randomised, controlled trial. J Bone Joint Surg Br 2005;87:829-36. [CrossRef]

7. Catalano LW 3rd, Cole RJ, Gelberman RH, Evanoff BA, Gilula LA, Borrelli J Jr. Displaced intra-articular fractures of the distal aspect of the radius. Long-term results in young adults after open reduction and internal fixation. J Bone Joint Surg Am 1997;79:1290-302. [CrossRef]

8. Leung F, Tu YK, Chew WY, Chow SP. Comparison of external and percutaneous pin fixation with plate fixation for intra-articular distal radial fractures. A randomized study. J Bone Joint Surg Am 2008;90:16-22.

9. Bahari-Kashani M, Taraz-Jamshidy MH, Rahimi H, Ashraf H, Mirkazemy M, Fatehi A, et al. Outcomes of pin and plaster versus locking plate in distal radius intraarticular fractures. Trauma Mon 2013;17:380-5.

10. Rozental TD, Blazar PE, Franko OI, Chacko AT, Earp BE, Day CS. Functional outcomes for unstable distal radial fractures treated with open reduction and internal fixation or closed reduction and percutaneous fixation. A prospective randomized trial. J Bone Joint Surg Am 2009;91:1837-46. [CrossRef]

11. Yoon JO, You SL, Kim JK. Intra-articular comminution worsens outcomes of distal radial fractures treated by open reduction and palmar locking plate fixation. J Hand Surg Eur Vol 2017;42:260-5. [CrossRef]

12. Egol K, Walsh M, Tejwani N, McLaurin T, Wynn C, Paksima N. Bridging external fixation and supplementary Kirschner-wire fixation versus volar locked plating for unstable fractures of the distal radius: a randomised, prospective trial. J Bone Joint Surg Br 2008;90:1214-21. [CrossRef]

13. Brennan SA, Kiernan C, Beecher S, O’Reilly RT, Devitt BM, Kearns SR, et al. Volar plate versus $\mathrm{k}$-wire fixation of distal radius fractures. Injury 2016;47:372-6. [CrossRef]

14. Knirk JL, Jupiter JB. Intra-articular fractures of the distal end of the radius in young adults. J Bone Joint Surg Am 1986;68:647-59. [CrossRef]

15. Lutz M, Arora R, Krappinger D, Wambacher M, Rieger M, Pechlaner S. Arthritis predicting factors in distal intraarticular radius fractures. Arch Orthop Trauma Surg 2011;131:1121-6. [CrossRef]

16. Chaudhry H, Kleinlugtenbelt YV, Mundi R, Ristevski B, Goslings JC, Bhandari M. Are Volar Locking Plates Superior to Percutaneous K-wires for Distal Radius Fractures? A Meta-analysis. Clin Orthop Relat Res 2015;473:3017-27. [CrossRef] 
ORİJINAL ÇALIŞMA - ÖZET

\section{Eklem içi uzanımlı distal radius kırıklarının tedavisinde kapalı redüksiyon perkütan pinlemeye karşın açık redüksiyon internal tespit: Dört yıllık sonuçlarımız \\ Dr. Sertac Saruhan, ${ }^{1}$ Dr. Cumhur Deniz Davulcu²}

${ }^{1}$ İzmir Bozyaka Eğitim ve Araştırma Hastanesi, Ortopedi ve Travmatoloji Kliniği, İzmir

2̇zmir Katip Çelebi Üniversitesi, Atatürk Eğitim ve Araştırma Hastanesi, Ortopedi ve Travmatoloji Kliniği, İzmir

AMAÇ: Bu çalışmada, eklem içi uzanımlı distal radius kırıklarının tedavisinde kapalı redüksiyon perkütan pinlemeye (KRPP) karşın açık redüksiyon internal fiksasyon (ARIF) tedavi yöntemlerinin dört yıllık sonuçları karşılaştııılmıştır.

GEREÇ VE YÖNTEM: KRPP ( $\mathrm{n}=19$; I I erkek ve sekiz kadın) ile tedavi edilen tek taraflı intraartiküler distal radius kırı̆̆ (tip $B$ ve C) olan ve ARIF yapılan ( $n=24$; 14 erkek ve 10 kadın) toplam 43 hasta geriye dönük olarak incelendi. Ortalama takip süresi kRPP grubunda 50.3 ay (I2-74) ve ARIF grubunda 45.2 ay (40-65) idi. Ortalama yaş KRPP grubunda 50.8 (29-73), ARiF grubunda 5 I.5 (19-75) idi. Hastalar son takipte fonksiyonel ve radyolojik olarak değerlendirildi.

BULGULAR: Takip, yaş ve cinsiyet açııından gruplar arasında istatistiksel olarak anlamlı fark yoktu. Her ne kadar kavrama gücü ve hareket aralı̆ı ile ilgili istatistiksel bir fark olmasa da ARIF grubunda kol, omuz ve el sorunları skoru (Q-DASH) daha iyiydi. Voler tilt ve radyal yükseklik ölçümleri ARIF grubunda istatistiksel olarak anlamlı derecede daha iyi idi. Dejeneratif artrit KRPP grubunda \%63 ve ARIF grubunda \%4I idi ve istatistiksel olarak anlamlı fark yoktu.

TARTIŞMA: Dört yıllık takip sonucunda volar plak ile ARIF yapılan eklem içi uzanımlı distal radius kırığı olan hasta grubunda, KRPP'den daha iyi fonksiyonel ve radyolojik sonuçlara sahip olduğu saptandı.

Anahtar sözcükler: Açık redüksiyon internal fiksasyon; distal radius kırıkları; eklem içi distal radius kırıkları; perkütan pinleme; volar kilitli plak.

Ulus Travma Acil Cerrahi Derg 2021;27(2):238-242 doi: 10.14744/tjtes.2020.28934 